\title{
Early Pennsylvanian xenacanth chondrichthyans from the Swisshelm Mountains, Arizona, USA
}

Gary D. Johnson and David W. Thayer

Acta Palaeontologica Polonica 54 (4), 2009: 649-668 doi: http://dx.doi.org/10.4202/app.2008.0051

Three genera of xenacanths, based on isolated teeth, occur in the lepospondyl (amphibian)-dominated fauna from the upper Black Prince Limestone (late Bashkirian). Orthacanthus donnelljohnsi sp. nov. teeth, with carinae lacking serrations on the compressed principal cusps, and only one intermediate cusp, represent both adult and juvenile teeth. Heterodonty occurs in both adult and juvenile dentitions. The absence of serrations is unique among Pennsylvanian species of Orthacanthus. Teeth with often highly asymmetrical bases with an aborally-flexed lingual marginal flange (= anterolingual shelf) and a single intermediate cusp are assigned to Triodus elpia sp. nov. A central foramen occurs in the base, unlike most other species; the moderately compressed principal cusps bear generally straight cristae. They represent the first reported occurrence of Triodus in the Paleozoic of North America. Five teeth, with cristae extending from the cusps onto their bases, belong to Bransonella. Two are questionably assigned to Bransonella nebraskensis, one to B. ?lingulata with its labio-lingually elongated apical button and smaller than normal intermediate cusp, and one each to Bransonella sp. "A" and "B". Bransonella sp. "A" has a base wider (labio-lingual) than long, the reverse of the other Bransonella teeth. Bransonella sp. "B" is distinctly different, as it lacks an intermediate cusp (as in some B. lingulata teeth), and the basal tubercle is beneath one of the cusps (with no evidence of deformity).

Key words: Chondrichthyes, Xenacanthiformes, Bransonelliformes, Orthacanthus, Triodus, Bransonella, Bashkirian, Arizona.

Gary D. Johnson [johnsong@ @mu.edu], Shuler Museum of Paleontology, Institute for the Study of Earth and Man, Southern Methodist University, PO Box 750274, Dallas, TX 75275-0274, USA; David W. Thayer, 611 S. 10th St., Williams, AZ 86046-2817, USA.

This is an open-access article distributed under the terms of the Creative Commons 
Attribution License (for details please see creativecommons.org), which permits unrestricted use, distribution, and reproduction in any medium, provided the original author and source are credited.

FoF Full text $(1.237 .3 \mathrm{kB})$ 